\title{
Cylindrocyclin A, a New Cytotoxic Cyclopeptide from Cylindrocarpon sp.
}

\author{
Daniela Weber, Gilda Erosa, Olov Sterner, Timm Anke \\ Dedicated to the memory of Professor Kenneth L. Rinehart.
}

Received: May 30, 2006 / Accepted: August 11, 2006

(C) Japan Antibiotics Research Association

\begin{abstract}
In the course of a screening of fungal extracts for new metabolites with cytotoxic activities cylindrocyclin A (1) was isolated. The producing strain was identified as Cylindrocarpon sp. by microscopy and ITS rDNA sequence analysis. $\mathbf{1}$ is a novel compound that exhibits cytotoxic acticity against six different cell lines with $\mathrm{IC}_{50}$ values ranging from 11 to $53 \mu \mathrm{M}$. 1 has no antibacterial or antifungal activity. The compound is a cyclic nonapeptide comprising three alanines, five leucines and one isoleucine. Four amino acids are $N$-methylated. Its structure was elucidated by spectroscopic methods.
\end{abstract}

Keywords new metabolite, cyclopeptide, cytotoxic, cylindrocarpon

\section{Introduction}

Many bacteria and fungi produce low-molecular weight peptides, depsipeptides, peptidolactones, and lipopeptide lactones with linear, branched or cyclic structures as secondary metabolites [1]. They are assembled by large multifunctional enzymes, the nonribosomal peptide synthetases (NRPS). The amino acids can be modified by e.g. $N$-methylation or acetylation. Since the stringency of amino acid recognition by the NRPS is not as high as in ribosomal protein synthesis in many cases a series of closely related cyclopeptides with exchanged amino acids are produced [2]. Many cyclopeptides have interesting biological activities and some of them have been commercialized e.g. cyclosporins and echinocandins. In a screening of fungal extracts we found that Cylindrocarpon sp. strain A101-96 produced a number of new cytotoxic cyclic nonapeptides. Here we describe the taxonomy of the producing strain, the fermentation, isolation, biological activities and the structure elucidation of the main component that we have named cylindrocyclin A (1).

\section{Materials and Methods}

Producing Organism

Cylindrocarpon sp. strain A101-96 was isolated from a twig by Prof. H. Anke (IBWF). The material was collected in Alpes Maritimes, France. The fungus was identified by microscopy and ITS sequence analysis as described previously [3]. Although Cylindrocarpon sp. strain A10196 showed the characteristics of the genus, the species could not be unequivocally determined. Voucher specimen and mycelial cultures are deposited in the culture collection of the IBWF e.V., Kaiserslautern. For maintenance on agar slants the fungus was grown in YMG medium ( $\mathrm{g} / \mathrm{liter})$ : yeast extract 4 , malt extract 10 , glucose 10 and agar $1.4 \%$ for solid media. The $\mathrm{pH}$ was adjusted to 5.5.

\section{Fermentation}

Fermentations were carried out in a Biolafitte C6 fermentor containing 20 liters of YMG medium with aeration (3 liters

G. Erosa, O. Sterner: Division of Organic Chemistry, Lund University, P.O.B. 124, S-22100 Lund, Sweden
T. Anke (Corresponding author), D. Weber: Institute of Biotechnology and Drug Research, Erwin-Schrödinger-Str. 56, D67663 Kaiserslautern, Germany,

E-mail: timm.anke@ibwf.uni-kl.de 
air/minute) and stirring $(120 \mathrm{rpm})$ at room temperature. A well-grown culture (in $250 \mathrm{ml}$ YMG medium in a $500 \mathrm{ml}$ Erlenmeyer flask grown at $22^{\circ} \mathrm{C}$ and $120 \mathrm{rpm}$ ) was used as inoculum. When the glucose was completely consumed (after 2 3 days), the culture fluid was separated from the mycelia by filtration. The culture broth was passed through Mitsubishi Diaion HP21 resin and washed with 1.5 liters of $\mathrm{H}_{2} \mathrm{O} / \mathrm{MeOH}(1: 1)$. The active components were eluted with $\mathrm{MeOH}$ and the organic phase concentrated in vacuo.

\section{Isolation of the Compounds}

The crude extract of the methanol fraction (see above, $541 \mathrm{mg})$ was applied onto a column $(2.5 \times 10 \mathrm{~cm})$ containing silica gel (Merck 60, 0.063 0.2 mm). An enriched product $(96 \mathrm{mg})$ was obtained after elution with ethyl acetate/MeOH $(3: 1)$. Preparative HPLC (Merck Lichrosorb $^{\circledR}$ RP $18,7 \mu \mathrm{m}$; column $25 \times 250 \mathrm{~mm}$; flow $15 \mathrm{ml} /$ minute; gradients: $\mathrm{H}_{2} \mathrm{O}-\mathrm{MeCN} 50 \sim 75 \%$ in 10 minutes, $75 \sim 100 \%$ in 15 minutes, 10 minutes at 100\%) yielded $10 \mathrm{mg}$ of an enriched product $(\mathrm{Rt}=30 \sim 33$ minutes). This was separated by analytical HPLC (Zorbax Eclipse XDB Phenyl $4.6 \times 150 \mathrm{~mm}, 5 \mu \mathrm{m}$, Fa. Agilent; Flow: $2.5 \mathrm{ml} /$ minute; isocratic: $55 \% \mathrm{MeCN}$; temperature: $30^{\circ} \mathrm{C}$ ) and yielded $7 \mathrm{mg}$ of $\mathbf{1}(\mathrm{Rt}=6.07$ minutes).

\section{Spectroscopy}

${ }^{1} \mathrm{H}$ NMR $(500 \mathrm{MHz})$ and ${ }^{13} \mathrm{C}$ NMR $(125 \mathrm{MHz})$ were recorded at room temperature with a Bruker DRX500 spectrometer with an inverse multinuclear $5 \mathrm{~mm}$ probe equipped with a shielded gradient coil. The spectra were recorded in $\mathrm{CDCl}_{3}$, and the solvent signals (7.26 and $77.0 \mathrm{ppm}$, respectively) were used as reference. The chemical shifts $(\delta)$ are given in ppm, and the coupling constants $(J)$ in Hz. COSY, HMQC and HMBC experiments were recorded with gradient enhancements using sine shaped gradient pulses. For the 2D heteronuclear correlation spectroscopy the refocusing delays were optimised for ${ }^{1} J_{\mathrm{CH}}=145 \mathrm{~Hz}$ and ${ }^{\mathrm{n}} J_{\mathrm{CH}}=10 \mathrm{~Hz}$. The raw data were transformed and the spectra were evaluated with the standard Bruker XWIN-NMR software (rev. 010101). LC-MS spectra were recorded with a HP 1100; APCI, positive/negative mode, while the HRESIMS spectrum was recorded with a Micromass Q-TOF MICRO instrument with the resolution 5000 in positive ion mode. The instrument was calibrated with phosphoric acid $(0.1 \%$ in water: acetonitrile 5:5) and the reference ion at 980.7768 was used as lock mass. The IR spectra were recorded with a Bruker IFS 48 spectrometer, the melting point (uncorrected) were determined with a Reichert microscope, and the optical rotations were measured with a PerkinElmer 141 polarimeter at $22^{\circ} \mathrm{C}$.

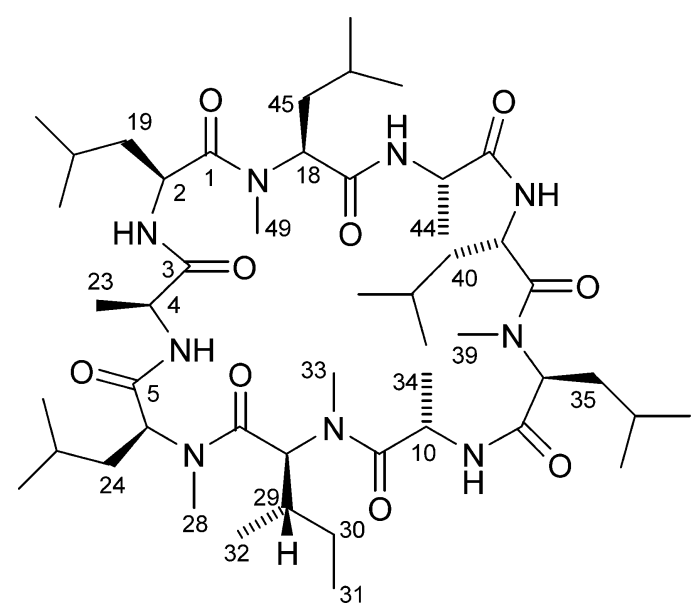

Fig. 1 Structure of cylindrocyclin A (1).

\section{Cylindrocyclin A (1)}

1 was obtained as a white powder, $\mathrm{mp} 220^{\circ} \mathrm{C}$ (decomp.). $[\alpha]_{\mathrm{D}}^{22}-5^{\circ}$ (c 0.5 in DMSO). IR (KBr) 3297, 2959, 1636, 1533 , and $1086 \mathrm{~cm}^{-1}$. ${ }^{1} \mathrm{H}$ and ${ }^{13} \mathrm{C}$ NMR data are given in Table 1. HRMS (ESI, $\mathrm{M}+\mathrm{H}^{+}$) found $\mathrm{m} / \mathrm{z}$ 948.6851, $\mathrm{C}_{49} \mathrm{H}_{90} \mathrm{~N}_{9} \mathrm{O}_{9}$ requires 948.6862 . The L-configuration of the amino acids contained in cylindrocyclin $\mathrm{A}$ was determined after hydrolysis using Marfey's reagent and HPLC analysis of the diastereomers (column: Zorbax eclipse XDB Phenyl $3.5 \mu \mathrm{m}, 3 \times 150 \mathrm{~mm} ; 65 \%$ water containing $0.1 \%$ formic acid, $35 \%$ acetonitrile; $0.6 \mathrm{ml} /$ minute) according to [4]. The retention times observed were for L-Ala: 2.7, L-Leu: 6.4, NMe-L-Leu: 7.8 and NMe-L-Ile: 8.3 minutes. They were identical with authentical derivatives of L-Ala, L-Leu, NMe-L-Leu and NMe-L-Ile prepared the same way.

\section{Biological Assays}

Antimicrobial activities were determined in the agar plate diffusion assay as described previously [5]. Inhibition of growth of germinated seeds of Setaria italica and Lepidium sativum was tested as described by Anke et al. [5]. Nematicidal activity was measured as described previously [6].

Colo-320 cells (DSMZ ACC 144, human colo adenocarcinoma), Jurkat cells (ATCC TIB 152, human acute T cell leukemia), L1210 (ATCC CCI 219), and HL60 cells (DSMZ ACC 3, human promyelocytic leukemia) were grown in RPMI 1640 medium (GIBCO, BRL), MDAMB-231 (ATCC HTB26) cells and MCF-7 cells in D-MEM medium (GIBCO, BRL). The medium was supplemented with $10 \%$ fetal calf serum (FCS) (GIBCO, BRL), $65 \mu \mathrm{g} / \mathrm{ml}$ of penicillin $\mathrm{G}$ and $100 \mu \mathrm{g} / \mathrm{ml}$ of streptomycin sulfate. The cells were maintained in a humidified atmosphere containing $5 \%$ of $\mathrm{CO}_{2}$ at $37^{\circ} \mathrm{C}$. 
Cytotoxicity was measured in microtiter plates with $1 \sim 5 \times 10^{5}$ cells $/ \mathrm{ml}$ medium. Cells were incubated with and without test compounds. In addition to a microscopic examination after 24,48 , and 72 hours, the effect on the growth of monolayer cell lines was measured by Giemsa staining. The viability of suspension cells was measured in a test based on XTT (2,3-bis(2-methoxy-4-nitro-5-sulfophenyl)-2H-tetrazolium-5-carboxanilide).

\section{Results and Discussion}

Both the typical morphological characteristics and the ITS sequence were in full accordance with the genus Cylindrocarpon. The sequence identity to Cylindrocarpon faginatum (CBS 217.67) AY677277.1 was 98\% and to Neonectria ramulariae AJ279446.1 97\%. Nectria and Neonectria are teleomorphs of the anamorph Cylindrocarpon. A number of cyclosporins have been obtained from Cylindrocarpon [7]. 1 was obtained as described in the experimental section. High resolution mass spectrometry suggested that its elemental composition was $\mathrm{C}_{49} \mathrm{H}_{89} \mathrm{~N}_{9} \mathrm{O}_{9}$, and this was supported by the 1D NMR spectra. 1 consequently had ten unsaturations, and the presence of only nine signals for unsaturated carbons, all as carbonyl groups, in the ${ }^{13} \mathrm{C}$ NMR spectrum indicated that the compound contained one ring. Further analysis of the 1D NMR data (shown in Table 1) clearly suggested that $\mathbf{1}$ was made up from nine amino acids, including four that were $\mathrm{N}$-methylated. Careful analysis of the COSY spectrum, confirmed by the HMBC data, revealed that there were two leucines, three $\mathrm{N}$-methylleucines, three alanines and one $N$-methylisoleucine. Because all five of the nonmethylated nitrogens were observed to be protonated $\mathbf{1}$ was deduced to be a cyclic nonapeptide. To establish the structure, the COSY correlations between the $\mathrm{NH}$ as well as the $\mathrm{N}-\mathrm{CH}_{3}$ protons and the $\alpha$-protons were established (long range ${ }^{1} \mathrm{H}-{ }^{1} \mathrm{H}$ couplings between the $N$-methyl protons and the $\alpha$-methine protons were clearly visible in a high resolution COSY experiment), and the HMBC correlations between the same protons as well as the $\alpha$ - and $\beta$-protons and the carbonyl carbons. Confirmation was obtained from the HMBC correlations between the $\mathrm{NH}$, the $\mathrm{N}-\mathrm{CH}_{3}$ and the $\beta$-protons and the $\alpha$-carbons. Starting with the NH:s, COSY correlations from $2-\mathrm{NH}$ via $2-\mathrm{H}, 19-\mathrm{H}_{2}$ and $20-\mathrm{H}$ to $21-\mathrm{H}_{3}$ and $22-\mathrm{H}_{3}$, from $4-\mathrm{NH}$ via $4-\mathrm{H}$ to $23-\mathrm{H}_{3}$, from $10-$ $\mathrm{NH}$ via $10-\mathrm{H}$ to $34-\mathrm{H}_{3}$, from $14-\mathrm{NH}$ via $14-\mathrm{H}, 40-\mathrm{H}_{2}$ and $41-\mathrm{H}$ to $42-\mathrm{H}_{3}$ and $43-\mathrm{H}_{3}$, and from $16-\mathrm{NH}$ via $16-\mathrm{H}$ to $44-$ $\mathrm{H}_{3}$, established the obvious proton spin systems in three alanines and two leucines. The COSY correlations from $28-\mathrm{H}_{3}$ via $6-\mathrm{H}, 24-\mathrm{H}_{2}$ and $25-\mathrm{H}$ to $26-\mathrm{H}_{3}$ and $27-\mathrm{H}_{3}$, from
Table $1{ }^{1} \mathrm{H} \quad(500 \mathrm{MHz}) \quad(\delta ;$ multiplicity; $J)$ and ${ }^{13} \mathrm{C}$ (125 MHz) ( $\delta$; multiplicity) NMR data for $\mathbf{1}$

\begin{tabular}{|c|c|c|c|c|c|}
\hline C & ${ }^{1} \mathrm{H}$ & ${ }^{13} \mathrm{C}$ & C & ${ }^{1} \mathrm{H}$ & ${ }^{13} \mathrm{C}$ \\
\hline 1 & - & 172.7; s & 28 & $2.84 ; s$ & $28.7 ; \mathrm{q}$ \\
\hline 2 & 4.85; m & $48.8 ; d$ & 29 & 2.26; m & $33.2 ; d$ \\
\hline 3 & - & 173.1; s & 30 & 1.47/1.13; m & $25.4 ; t$ \\
\hline 4 & 4.86; m & $47.8 ; d$ & 31 & $0.90 ; t ; 8.1$ & $9.4 ; \mathrm{q}$ \\
\hline 5 & - & 168.2; s & 32 & $0.94 ; d ; 6.6$ & 16.0; q \\
\hline 6 & $4.91 ; m$ & $58.6 ; d$ & 33 & $3.23 ; s$ & 31.0; q \\
\hline 7 & - & 170.4; s & 34 & $1.13 ; d ; 6.6$ & $18.6 ; q$ \\
\hline 8 & $5.20 ; d ; 11.2$ & $55.1 ; d$ & 35 & 1.75/1.58; m & $34.8 ; t$ \\
\hline 9 & - & 173.8; s & 36 & 1.48; m & $24.8 ; d$ \\
\hline 10 & $4.84 ; m$ & 45.6; d & 37 & $0.93 ; d ; 6.7$ & $22.7 ; \mathrm{q}$ \\
\hline 11 & - & 168.5; s & 38 & $0.88 ; d ; 6.7$ & 22.5; q \\
\hline 12 & 4.92; m & $53.7 ; d$ & 39 & $2.88 ; \mathrm{s}$ & 29.7; q \\
\hline 13 & - & 173.6; s & 40 & 1.31/1.08; m & $43.6 ; t$ \\
\hline 14 & $4.94 ; m$ & $47.5 ; d$ & 41 & 1.65; m & 24.6; d \\
\hline 15 & - & 172.9; s & 42 & $1.04 ; d ; 6.7$ & 23.8; q \\
\hline 16 & 4.48; m & $51.7 ; d$ & 43 & $0.79 ; d ; 6.7$ & 23.5; q \\
\hline 17 & - & 169.5; s & 44 & $1.48 ; d ; 7.3$ & $18.4 ; \mathrm{q}$ \\
\hline 18 & 4.45; m & $59.1 ; d$ & 45 & 2.21/1.50; m & $37.4 ; \mathrm{t}$ \\
\hline 19 & $1.75 / 1.47 ; m$ & $40.2 ; \mathrm{t}$ & 46 & 1.60; m & $24.7 ; d$ \\
\hline 20 & 1.89; m & $25.5 ; d$ & 47 & $0.95 ; d ; 6.6$ & $23.1 ; q$ \\
\hline 21 & $1.07 ; d ; 6.4$ & $21.5 ; q$ & 48 & $0.95 ; d ; 6.6$ & $23.1 ; q$ \\
\hline 22 & $1.01 ; d ; 6.7$ & 23.6; q & 49 & $2.80 ; \mathrm{s}$ & $29.4 ; q$ \\
\hline 23 & $1.26 ; \mathrm{d} ; 7.0$ & $17.7 ; q$ & 2-NH & $6.75 ; d ; 5.0$ & \\
\hline 24 & 2.52/1.08; m & $38.3 ; t$ & $4-\mathrm{NH}$ & $8.18 ; d ; 9.4$ & \\
\hline 25 & $1.67 ; m$ & $25.4 ; d$ & $10-\mathrm{NH}$ & $7.24 ; d ; 8.3$ & \\
\hline 26 & $1.04 ; d ; 6.7$ & $21.5 ; q$ & $14-\mathrm{NH}$ & 7.57; d; 8.7 & \\
\hline 27 & $1.04 ; d ; 6.7$ & $21.3 ; \mathrm{q}$ & $16-\mathrm{NH}$ & $8.12 ; d ; 8.7$ & \\
\hline
\end{tabular}

The spectra were recorded in $\mathrm{CDCl}_{3}$, and the solvent signals (7.26 and $77.0 \mathrm{ppm}$, respectively) were used as reference. The chemical shifts $(\delta)$ are given in ppm and the coupling constants $J$ are given in $\mathrm{Hz}$. The multiplicities of the carbon signals were determined indirectly from HMOC experiments.

$33-\mathrm{H}_{3}$ via $8-\mathrm{H}$ and $29-\mathrm{H}$ to $32-\mathrm{H}_{3}$ as well as via $8-\mathrm{H}, 29-\mathrm{H}$ and $30-\mathrm{H}_{2}$ to $31-\mathrm{H}_{3}$, from $39-\mathrm{H}_{3}$ via $12-\mathrm{H}, 35-\mathrm{H}_{2}$ and $36-\mathrm{H}$ to $37-\mathrm{H}_{3}$ and $38-\mathrm{H}_{3}$, and from $49-\mathrm{H}_{3}$ via $18-\mathrm{H}, 45-\mathrm{H}_{2}$ and $46-\mathrm{H}$ to $47-\mathrm{H}_{3}$ and $48-\mathrm{H}_{3}$, established the proton spin systems in remaining three $N$-methylleucines and the $N$ methylisoleucine. All NH's as well as the $\mathrm{N}$-methyl protons gave HMBC correlations to both the neighboring $\alpha$-carbon and the carbonyl carbon. Consequently, 2-NH gave HMBC correlations to $\mathrm{C}-2$ and $\mathrm{C}-3,4-\mathrm{NH}$ gave $\mathrm{HMBC}$ correlations to $\mathrm{C}-4$ and $\mathrm{C}-5,28-\mathrm{H}_{3}$ gave $\mathrm{HMBC}$ correlations to $\mathrm{C}-6$ and $\mathrm{C}-7,33-\mathrm{H}_{3}$ gave $\mathrm{HMBC}$ correlations to $\mathrm{C}-8$ and $\mathrm{C}-9,10-\mathrm{NH}$ gave $\mathrm{HMBC}$ correlations to $\mathrm{C}-10$ and $\mathrm{C}-11,39-\mathrm{H}_{3}$ gave $\mathrm{HMBC}$ correlations to $\mathrm{C}-12$ and $\mathrm{C}-13,14-\mathrm{NH}$ gave $\mathrm{HMBC}$ 

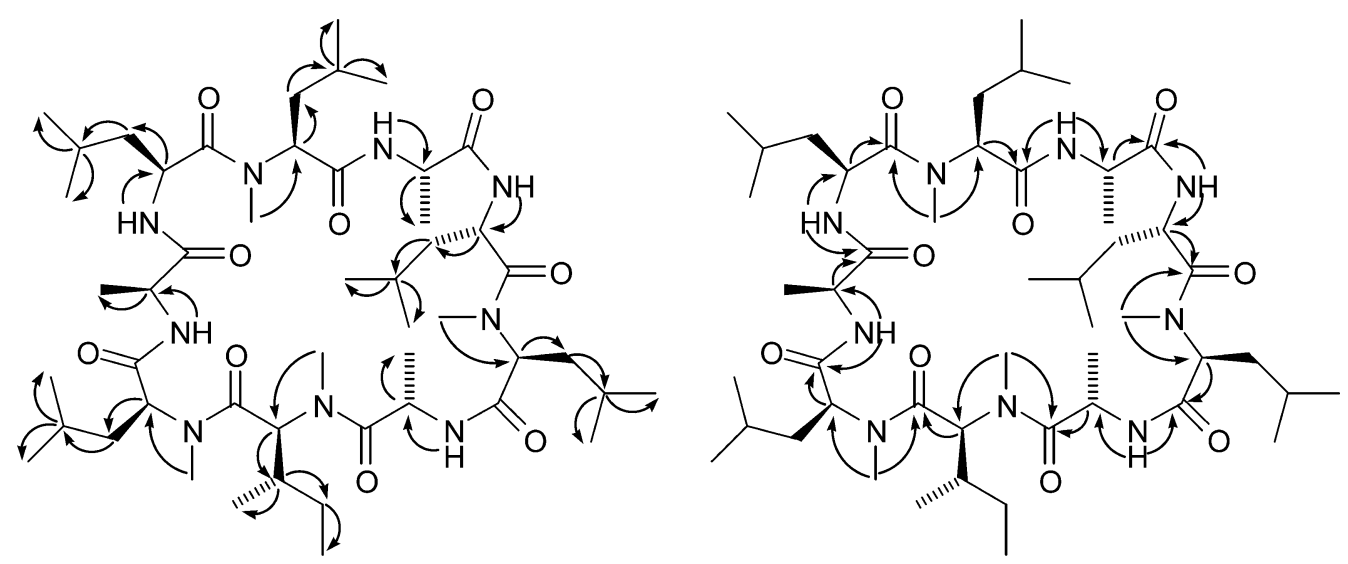

Fig. 2 Pertinent COSY (left) and HMBC (right) correlations observed with 1.

correlations to $\mathrm{C}-14$ and $\mathrm{C}-15,16-\mathrm{NH}$ gave $\mathrm{HMBC}$ correlations to $\mathrm{C}-16$ and $\mathrm{C}-17$, and $49-\mathrm{H}_{3}$ gave $\mathrm{HMBC}$ correlations to $\mathrm{C}-18$ and $\mathrm{C}-1$. In addition, all $\alpha$-protons gave HMBC correlations to their corresponding carbonyl carbon. 2-H gave a HMBC correlation to $\mathrm{C}-1,4-\mathrm{H}$ gave a $\mathrm{HMBC}$ correlation to $\mathrm{C}-3,6-\mathrm{H}$ gave a $\mathrm{HMBC}$ correlation to $\mathrm{C}-5,8-\mathrm{H}$ gave a $\mathrm{HMBC}$ correlation to $\mathrm{C}-7,10-\mathrm{H}$ gave a HMBC correlation to C-9, 12-H gave a HMBC correlation to $\mathrm{C}-11,14-\mathrm{H}$ gave a $\mathrm{HMBC}$ correlation to $\mathrm{C}-13,16-\mathrm{H}$ gave a $\mathrm{HMBC}$ correlation to $\mathrm{C}-15$, and $18-\mathrm{H}$ gave a $\mathrm{HMBC}$ correlation to $\mathrm{C}-17$. All pertinent COSY and HMBC correlations are summarized in Figure 2. In this way it was possible to establish all peptide bonds unequivocally, and thereby the structure of $\mathbf{1}$. To determine the absolute configuration of the compound, it was subjected to acidic hydrolysis to produce the individual amino acids that were derivatized with 1-fluoro-2,4-dinitrophenyl-5-L-alanine amide, according to the procedure reported in reference [4]. The hydrolysis mixture was analyzed by the LC-MS methods described above and comparing peaks with D- and L-amino acids standards we determined that all nine amino acids in $\mathbf{1}$ were of the L configuration. The structure shown in Figure 1 consequently represents the absolute configuration of $\mathbf{1}$. In addition, our strain was found to produce the known ilicicolins $\mathrm{C}, \mathrm{D}, \mathrm{E}$, and $\mathrm{F}$ (data not shown), although no cyclosporins or roridins could be isolated $[8,9]$.

The cytotoxic activities of $\mathbf{1}$ against human and mouse cell lines are shown in Table 2. The compound did not exhibit either antimicrobial nor nematicidal activities up to concentrations of $100 \mu \mathrm{g} /$ paper disk or $100 \mu \mathrm{g} / \mathrm{ml}$ respectively. No phytotoxic effects against Setaria italica and Lepidium sativum were found at $500 \mu \mathrm{g} / \mathrm{ml}$.
Table 2 Cytotoxic activities of 1

\begin{tabular}{lc}
\hline \multicolumn{1}{c}{ Cell line } & $\mathrm{IC}_{50}(\mu \mathrm{M})$ \\
\hline COLO-320 & 11 \\
HL-60 & 11 \\
L1210 & 11 \\
Jurkat & 11 \\
MDA-MB-231 & 42 \\
MCF-7 & 53 \\
\hline
\end{tabular}

Acknowledgments We thank Prof. H. Anke (IBWF) for Cylindrocarpon sp. A101-96 and Ms. A. Meffert for expert technical assistance.

\section{References}

1. Hornbogen T, Zocher R. Biosynthesis of $N$-methylated peptides in fungi. In Handbook of industrial mycology. Ed., Zhiqiang An, pp. 449-477, Marcel Dekker, New York (2005)

2. Kleinkauf H, von Döhren H. Biosynthesis of cyclosporins and related peptides. In Fungal Biotechnology. Ed., T. Anke, pp. 146-161, Chapman \& Hall, Weinheim (1997)

3. Weber D, Gorzalczany S, Martino V, Acevedo C, Sterner O, Anke T. Metabolites from endophytes of the medicinal plant Erythrina crista-galli. Z Naturforsch 60c: 467-477 (2005)

4. Gordon-Adamson J, Hoang T, Crivici A, Lajoie GA. Use of Marfey's reagent to quatitate racemization upon anchoring of amino acids to solid support for peptide synthesis. Anal Biochem 202: 210-214 (1992)

5. Anke H, Bergendorff O, Sterner O. Assay of the biological activities of guaiane sesquiterpenoids isolated from the fruit bodies of edible Lactarius species. Food Chem Toxicol 27: 
393-398 (1989)

6. Stadler M, Mayer A, Anke H, Sterner O. Fatty acids and other compounds with nematicidal activity from cultures of Basidiomycetes. Planta Med 60: 128-132 (1994)

7. Rüegger A, Kuhn M, Lichti H, Loosli HR, Huguenin R, Quiquerez C, von Wartburg A. Cyclosporin A ein immunsuppressiv wirksamer Peptimetabolit aus Trichoderma polysporum (Link ex. Pers.) Rifai. Helv Chim Acta 59: 1075-1092 (1976)
8. Gutiérrez M, Theoduloz C, Rodríguez J, Lolas M, SchmedaHirschmann G. Bioactive metabolites from the fungus Nectria galligena, the main apple canker agent in chile. J Agric Food Chem 53: 7701-7708 (2005)

9. Matsumoto M, Minato H, Tori K, Ueyama M. Structures of isororidin E, epoxyroridin E, and epoxy- and diepoxyroridin $\mathrm{H}$, new metabolites isolated from Cylindrocarpon species determined by carbon-13 and hydrogen-1 NMR spectroscopy. Tetrahedron Lett 47: 4093-4096 (1977) 